\title{
Pengaruh Ukuran Perusahaan, Profitabilitas dan Resiko Bisnis terhadap Struktur Modal pada Perusahaan Manufaktur (LQ45) Tahun 2015-2018
}

\author{
*Savitri Ashifa Diastuti, Cholifah, Enny Istanti \\ Program Studi Manajemen Fakultas Ekonomi dan Bisnis \\ Universitas Bhayangkara Surabaya, Indonesia
}

DOI: 10.46821/benchmark.v1i2.149

\begin{abstract}
Abstrak
Setiap lembaga maupun perusahaan pasti ada yang namanya manajemen keuangan.Manajemen keuangan sangat penting guna memantau dan melihat nilai dari sebuah lembaga maupun perusahaan.Penelitian ini bertujuan untuk menguji dan menganalisis apakah variabel Ukuran Perusahaan, Profitabilitas dan Resiko Bisnis berpengaruh secara simultan dan signifikan, berpengaruh secara parsial dan signifikan dan variabel mana yang berpengaruh dominan terhadap Struktur Modal. Metode pengambilan data yang digunakan dalam penelitian ini adalah purposive sampling dengan Populasi sebanyak 45 perusahaan dan 8 Perusahaan sebagai sampel. Penelitian ini menggunakan Teknik Analisis data regresi linier dibantu dengan Program SPSS 22. Hasil penelitian menunjukkan bahwa Ukuran Perusahaan, profitabilitas dan Resiko bisnis berpengaruh simultan dan signifikan terhadap Struktur Modal. Uji Parsial diperoleh Profitabilitas berpengaruh negatif dan signifikan, sedangkan ukuran perusahaan dan resiko bisnis berpengaruh positif dan signifikan terhadap struktur modal. Uji dominan diperoleh Resiko Bisnis memiliki nilai terbesar dibanding dengan variabel lain.

Kata kunci: Ukuran Perusahaan, Profitabilitas, Resiko Bisnis dan Struktur Modal

Abstract

Every institution and company has financial management. Financial management is very important to monitor and see the value of an institution or company. This study aims to examine and analyze whether the variable Company Size, Profitability and Business Risk simultaneously and significantly influences, partially and significantly influences and which variable has the dominant influence on the Capital Structure. The data collection method used in this study was purposive sampling with a population of 45 companies and 8 companies as samples. This study uses linear regression data analysis techniques assisted with the SPSS 22 Program. The results of the study show that company size, profitability and business risk have a simultaneous and significant effect on capital structure. Partial test obtained by Profitability has negative and significant effect, while company size and business risk have positive and significant effect on capital structure. The dominant test obtained by Business Risk has the greatest value compared to other variables.
\end{abstract}

Keywords: Company Size, Profitability, Business Risk and Capital Structure.

\section{PENDAHULUAN}

Setiap lembaga maupun perusahaan pasti ada yang namanya manajemen keuangan. Manajemen keuangan sangat penting guna memantau dan melihat nilai dari sebuah lembaga maupun perusahaan. Pengertian terkait manajemen keuangan pun mulai

*Corresponding Author:

Hal: $114-121$

Email: ashifa.shasa@gmail.com 
mengalami perkembangan yang pengertian awalnya hanya berupa sebuah kegiatan untuk bisa memperoleh dana hingga kini pengertian manajemen keuangan diganti menjadi sebuah kegiatan yang mengutamakan memperoleh, menggunakan dana hingga mengelola aktiva. Manajemen keuangan memiliki 4 kegiatan yang dikenal dengan singkatan POAC yaitu Planning, Organizing, Actuating dan Controlling.

Manajemen Keuangan merupakan penggabungan dari ilmu dan seni yang membahas, mengkaji dan menganalisis tentang bagaimana seorang manajer keuangan dengan mempergunakan seluruh sumber daya perusahaan untuk mencari dana, mengelola dana, dan membagi dana dengan tujuan mampu memberikan profit atau kemakmuran bagi para pemegang saham dan suistainability (berkelanjutan) usaha bagi perusahaan.(Fahmi and Irham 2015).

Ketidak berhasilan manajemen dalam mengelola perusahaan adalah dengan melihat seberapa efektif penggunaan Ukuran Perusahaan, Profitabilitas dan Resiko Bisnis untuk meningkatkan Struktur Modal. Berdasarkan latar belakang yang telah dijelaskan sebelumnya, peneliti tertarik untuk melakukan penelitian dengan judul Pengaruh Ukuran Perusahaan, Profitabilitas dan Resiko Bisnis terhadap Struktur Modal Pada Perusahaan Manufaktur Yang Terdaftar Dalam Indeks LQ45Pada Tahun (20152018).

\section{TINJAUAN PUSTAKA}

\section{Ukuran Perusahaan}

Ukuran Perusahaan adalah salah satu faktor yang digunakan perusahaan untuk menentukan berapa besar kebijakan struktur modal dalam memenuhi besar aset suatu perusahaan (Ardiana, Agus., dan Adiyana, Sabo 2014). ukuran perusahan diukur dengan proksi berdasarkan total aset. Ukuran perusahaan dapat dirumuskan sebagai berikut:

Size $=\operatorname{Ln}($ Total Asset $)$

\section{Profitabilitas}

Margin laba bersih merupakan ukuran keuntungan dengan membandingkan antara laba bersih setelah bunga dan pajak dibandingkan dengan penjualan. Rasio ini menunjukkan pendapatan bersih perusahaan atas penjualan.(Kasmir 2017)

rumusnet profit margin adalah sebagai berikut:

Net Profit Margin=(Laba setelah pajak $) /($ Penjualan bersih $)$

\section{Resiko Bisnis}

Resiko bisnis perusahaan berpengaruh terhadap kelangsungan hidup perusahaan dan dimana perusahaan mampu untuk membayar utangnya. Tingkat Resiko bisnis pada perusahaan juga mempengaruhi minat pemodal untuk menanamkan dana pada perusahaan dan mempengaruhi kemampuan perusahaan untuk memperoleh dana dalam menjalankan kegiatan operasionalnya. Pengukuran Resiko bisnis dalam penelitian ini menggunakan standar deviasi dari (ROE) Return On Equity yang mengacu pada penelitian (Prabansari 2014) yaitu dengan formula sebagai berikut:

$\sigma R O E=\sqrt{\frac{\sum_{n-1}^{n} R O E_{i n}}{R O E}}-\overline{R O}$ 


\section{Struktur Modal}

Struktur Modal adalah hak atau bagian yang dimiliki oleh pemilik perusahaan yang ditujukan dalam pos modal (modal saham), surplus dan laba yang ditahan atau kelebihan aktiva yang dimiliki oleh perusahaan terhadap seluruh hutanghutangnya.(Munawir 2014)

Debt to Equity Ratio, merupakan rasio yang digunakan untuk menilai utang dengan ekuitas.Rasio ini berguna untuk mengetahui jumlah utang dibandingkan dengan modal yang dimiliki perusahaan. Rumus Debt to Equity Ratio adalah:

Debt to Equity Ratio $=($ Total Hutang $) /$ Equitas

\section{METODE PENELITIAN}

\section{Populasi}

Populasi merupakan subyek penelitian Menurut (Sugiyono 2014), populasi adalah wilayah generalisasi yang terdiri atas obyek/subyek yang mempunyai kualitas dan karakteristik tertentu yang ditetapkan oleh peneliti untuk dipelajari dan kemudian ditarik kesimpulannya. Jadi populasi bukan hanya orang, tetapi juga obyek dan benda-benda alam yang lain. Populasi juga bukan sekedar jumlah yang ada pada obyek/subyek yang dipelajari, tetapi meliputi seluruh karakteristik/sifat yang dimiliki oleh subyek atau obyek. Populasi yang digunakan dalam penelitian ini adalah perusahaan Manufaktur yang terdaftar dalam indeks LQ-45 yaitu 45 perusahaan Manufaktur yang go public.

\section{Sampel}

Menurut (Sugiyono 2014) definisi sampel yaitu sebagai berikut: "Sampel adalah bagian dari jumlah dan karakteristik yang dimiliki oleh populasi tersebut". Teknik yang digunakan dalam penelitian adalah purposive sampling yang mana sampel dipilih sesuai dengan kriteria-kriteria yang ditentukan. Kriteria perusahaan yang digunakan dalam penelitian ini adalah:

a. Perusahaan Manufaktur yang tergabung dalam indeks LQ-45 di BEI periode pengamatan 2015-2018.

b. Perusahaan yang selalu masuk dalam indeks LQ-45 per 31 Desember periode 20152018.

c. Perusahaan yang memberikan laporan secara lengkap periode pengamatan yaitu 2015-2018.

Tabel 1

Nama 8 Perusahaan Sampel

\begin{tabular}{cllc}
\hline No & Kode & Nama Emiten & Keterangan \\
\hline 1 & ASII & Astra International Tbk & Tetap \\
2 & GGRM & Gudang Garam Tbk & Tetap \\
3 & ICBP & Indofood CBP Sukses Makmur Tbk & Tetap \\
4 & INDF & Indofood Sukses Makmur Tbk & Tetap \\
5 & INTP & Indocement Tunggal Prakarsa Tbk & Tetap \\
6 & KLBF & Kalbe Farma Tbk & Tetap \\
7 & SMGR & Semen Indonesia (Persero) Tbk & Tetap \\
8 & UNVR & Unilever Indonesia Tbk & Tetap \\
\hline
\end{tabular}

Sumber: Bursa Efek Indonesia 


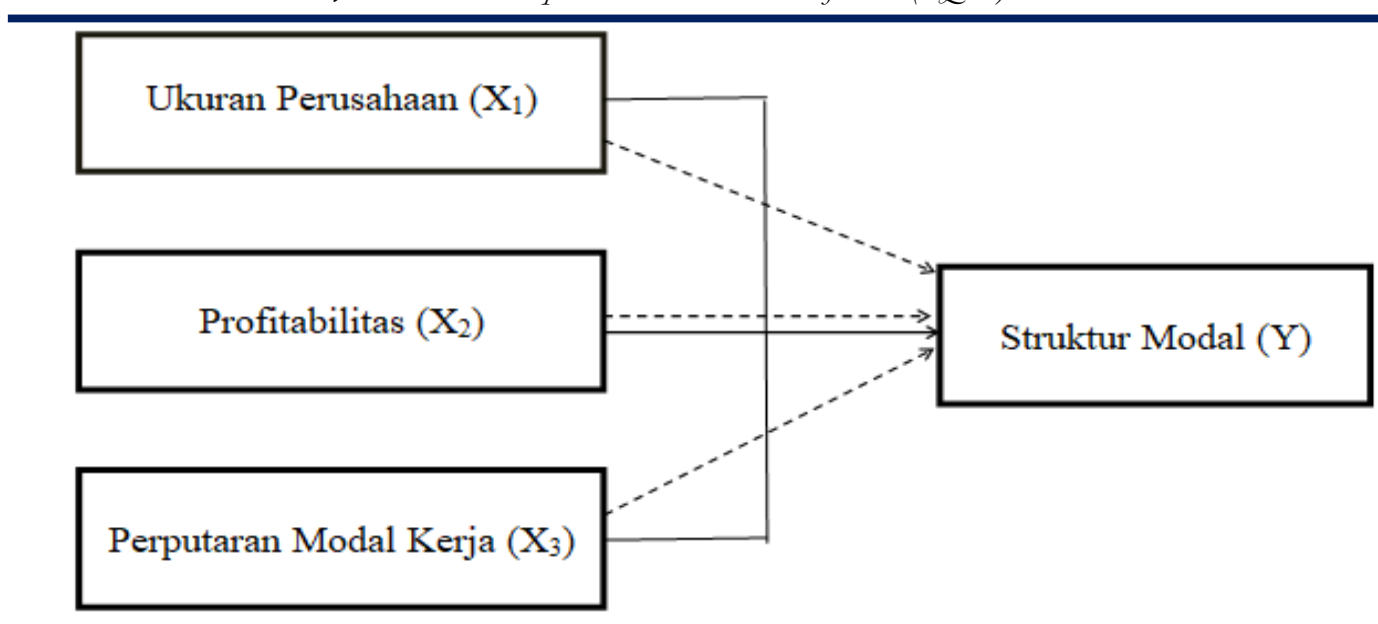

\section{Gambar 1 \\ Kerangka Konseptual}

\section{Hipotesis}

a. Bahwa Ukuran Perusahaan, Profitabilitas dan Resiko Bisnis secara simultan berpengaruh signifikan terhadap Struktur Modalpada perusahaan Manufaktur (LQ45).

b. Bahwa Ukuran Perusahaan, Profitabilitas dan Resiko Bisnis secara parsial berpengaruh signifikan terhadap Struktur Modalpada perusahaan Manufaktur (LQ45).

c. Bahwa Ukuran Perusahaan, secara Dominan berpengaruh signifikan terhadap Struktur Modalpada perusahaan Manufaktur (LQ45).

\section{HASIL ANALISIS DAN PEMBAHASAN}

\section{Analisis Koefisien Determinasi}

Koefisien determinasi bertujuan untuk mengukur sbeerapa jauh kemampuan model dalam menerangkan variasi variabel independen. Berikut ini adalah hasil analisis koefisien determinasi yang digambarkan dalam tabel 2 .

Pada tabel 2, menunjukkan bahwa dari hasil pengujian analis regresi berganda didapatkan nilai determinasi sebesar 0,916. Dengan demikian, dapat disimpulkan bahwa variabel bebas Ukuran Perusahaan, Profitabilitas dan Resiko Bisnis mampu menjelaskan dan memberikan informasi yang dibutuhkan untuk variabel terikat Struktur Modal adalah sebesar 0,916 atau sebesar 91,6\% sedangkan sisanya sebesar 8,4\% dipengaruhi oleh faktor-faktor lain yang berasal dari variabel model yang diteliti.

\section{Tabel 2}

\section{Hasil Uji Koefisien Determinasi} Model Summary ${ }^{\mathrm{b}}$

\begin{tabular}{lcccc}
\hline Model & R & R Square & Adjusted R Square & Std. Error of the Estimate \\
\hline 1 &, $957^{a}$ &, 916 &, 907 &, 19919 \\
\hline
\end{tabular}

a. Predictors: (Constant), X3, X1, X2

b. Dependent Variable: Y

Sumber: Data Diolah, 2020 


\begin{tabular}{|c|c|c|c|c|c|c|}
\hline \multicolumn{7}{|c|}{$\begin{array}{c}\text { Tabel } 3 \\
\begin{array}{c}\text { Hasil Analisis Regresi Linier Berganda } \\
\text { Coefficients }\end{array}\end{array}$} \\
\hline & \multirow[b]{2}{*}{ Model } & \multicolumn{2}{|c|}{$\begin{array}{c}\text { Unstandardized } \\
\text { Coefficients }\end{array}$} & \multirow{2}{*}{$\begin{array}{c}\begin{array}{c}\text { Standardized } \\
\text { Coefficients }\end{array} \\
\text { Beta }\end{array}$} & \multirow[b]{2}{*}{$\mathrm{t}$} & \multirow[b]{2}{*}{ Sig. } \\
\hline & & $\mathrm{B}$ & Std. Error & & & \\
\hline 1 & (Constant) & ,570 & ,110 & & 5,189 &, 000 \\
\hline & $\mathrm{X} 1$ & 196 & ,043 & 260 & 4,520 &, 000 \\
\hline & $\mathrm{X} 2$ &,- 038 & ,008 &,- 290 & $-4,626$ &, 000 \\
\hline & X3 & ,018 & ,001 & 1,072 & 17,202 &, 000 \\
\hline
\end{tabular}

a. Dependent Variable: Y

Sumber: Data Diolah, 2020

\section{Analisis Regresi Linier Berganda}

Analisis Regresi Linier Berganda digunakan untuk mengetahui seberapa besar pengaruh faktor yang digunakan dalam model penelitian yaitu Ukuran Perusahaan (X1), Profitabilitas (X2), Resiko Bisnis (X3) dalam memprediksi Struktur Modalpada perusahaan Manufaktur yang terdaftar di LQ45. Adapun hasil analisis regresi linier berganda Tabel 3.

Adapun persamaan regresi yang didapatkan adalah sebagai berikut:

$\mathrm{Y}=\mathrm{a}+\mathrm{b} 1 \mathrm{X} 1+\mathrm{b} 2 \mathrm{X} 2+\mathrm{b} 3 \mathrm{X} 3$

$\mathrm{Y}=0,570+0,196 \mathrm{X} 1-0,38 \mathrm{X} 2+0,018 \mathrm{X} 3$

Berdasarkan hasil persamaan diatas dapat diuraikan sebagai berikut:

a. Konstanta (a)

Besarnya nilai konstanta (a) adalah 0,570 menunjukkan bahwa jika variabel independen yang terdiri dari Ukuran Perusahaan, Profitabilitas dan Resiko Bisnis sama dengan 0 maka variabel terikat sebesar 0,570

b. Ukuran Perusahaan

Besarnya nilai koefisien (b1) adalah 0,198 yang menunjukkan arah hubungan positif antara Ukuran Perusahaan dan Struktur Modal, yaitu jika variabel Ukuran Perusahaan naik sebesar 1 (satu) satuan maka perubahan Struktur Modalakan naik sebesar 0,198 dengan asumsi faktor-faktor yang lain tetap.

c. Profitabilitas

Besarnya nilai koefisien (b2) adalah -0,038 yang menunjukkan arah hubungan negatif antara Profitabilitas dan Struktur Modal, yaitu jika variabel Profitabilitas naik sebesar 1 (satu) satuan maka perubahan Struktur Modal akan turun sebesar -0,038 dengan asumsi faktor-faktor yang lain tetap.

d. Risiko Bisnis

Besarnya nilai koefisien (b3) adalah 0,018 yang menunjukkan arah hubungan positif antara Resiko Bisnis dan Struktur Modal, yaitu jika variabel Resiko Bisnis naik sebesar 1 (satu) satuan maka perubahan Struktur Modal akan naik sebesar 0,018 dengan asumsi faktor-faktor yang lain tetap. 


\section{Tabel 4}

Hasil Perhitungan Uji F

ANOVA $^{a}$

\begin{tabular}{lllllll}
\hline Model & & Sum of Squares & df & Mean Square & F & Sig. \\
\hline 1 & Regression & 12,120 & 3 & 4,040 & 101,825 &, $000^{\mathrm{b}}$ \\
& Residual & 1,111 & 28 &, 040 & & \\
& Total & 13,231 & 31 & & & \\
\hline
\end{tabular}

a. Dependent Variable: Y

b. Predictors: (Constant), X3, X1, X2

Sumber: Data Diolah, 2020

\section{Tabel 5}

Hasil Perhitungan uji t

Coefficients $^{\mathrm{a}}$

\begin{tabular}{|c|c|c|c|c|c|c|}
\hline & \multirow[b]{2}{*}{ Model } & \multicolumn{2}{|c|}{$\begin{array}{c}\text { Unstandardized } \\
\text { Coefficients }\end{array}$} & \multirow{2}{*}{$\begin{array}{c}\text { Standardized } \\
\text { Coefficients }\end{array}$} & \multirow[b]{2}{*}{$\mathrm{t}$} & \multirow[b]{2}{*}{ Sig. } \\
\hline & & B & Std. Error & & & \\
\hline \multirow[t]{4}{*}{1} & (Constant) & ,570 & ,110 & & 5,189 & 000 \\
\hline & $\mathrm{X} 1$ & ,196 & ,043 & 260 & 4,520 & ,000 \\
\hline & $\mathrm{X} 2$ &,- 038 & ,008 &,- 290 & $-4,626$ & ,000 \\
\hline & X3 & ,018 & ,001 & 1,072 & 17,202 & ,000 \\
\hline
\end{tabular}

a. Dependent Variable: Y

Sumber: Data Diolah, 2020

\section{Uji F}

Uji F digunakan untuk mengetahui variabel bebas Ukuran Perusahaan, Profitabilitas dan Resiko Bisnissecara simultan terdapat variabel terikat Struktur Modal.Pengujian ini dilakukan dengan membandingkan Fhitung dengan Ftabel serta dengan memperhatikan signifikasinya (Tabel 4).

Dari hasil uji $\mathrm{F}$ diperoleh $\mathrm{F}_{\text {hitung }}(101,825)>\mathrm{F}_{\text {tabel }}(2,95)$ dan nilai signifikan $(0,000)$ $<\alpha(0,05)$. Hal ini membuktikan bahwa $\mathrm{H}_{0}$ ditolak dan $\mathrm{H}_{1}$ diterima.Sehingga variabel bebas yang terdiri dari Ukuran Perushaan, Profitabilitas dan Resiko Bisnis berpengaruh secara simultan dan signifikan terhadap variabel terikat Struktur Modalpada perusahaan Manufaktur LQ45.

\section{Uji t}

Uji t digunakan untuk mengetahui pengaruh variabel bebas yang terdiri dari Ukuran Perushaan, Profitabilitas dan Resiko Bisnis berpengaruh secara parsial terhadap variabel terikatStruktur Modal.Pengujian ini dilakukan dengan membandingkan masing-masing thitung dengan ttabel variabel bebas serta dengan memperhatikan signifikannya (Tabel 5).

a. Pengaruh Ukuran Perusahaan (X1) terhadap Struktur Modal(Y)

Dari hasil uji t Tabel 5, didapatkan dinilai thitung sebesar 4,520 dengan tingkat signifikan sebesar 0,000. Oleh karena thitung 4,520> ttabel 2,048 dan nilai signifikansi yang dihasilkan sebesar 0,000 berarti lebih kecil dari 0,05 maka variabel 
Ukuran Perushaan(X1) berpengaruh positif dansignifikan terhadap Struktur Modal(Y) pada perusahaan Manufaktur LQ45.

b. Pengaruh Profitabilitas(X2) terhadap Struktur Modal(Y)

Dari hasil uji t Tabel 5, didapatkan nilai thitung sebesar -4,626 dengan tingkat signifikansi sebesar 0,000. Oleh karena itu thitung $-4,626<$ ttabel 2,048 dan nilai signifikansi yang dihasilkan sebesar 0,000 berarti lebih kecil dari 0,05 maka variabel Profitabilitas (X2) berpengaruh negatif dan signifikan terhadap Struktur Modal(Y) pada perusahaan Manufaktur yang terdaftar di BEI.

c. Pengaruh Resiko Bisnis (X3) terhadap Struktur Modal (Y)

Dari hasil uji t Tabel 5, didapatkan nilai thitung sebesar 17,202 dengan tingkat signifikansi sebesar 0,000. Oleh karena itu thitung 17,202 >ttabel 2,048 dan nilai signifikansi yang dihasilkan sebesar 0,000 berarti lebih kecil dari 0,05 maka variabel Resiko Bisnis (X3) berpengaruh positif dan signifikan terhadap Struktur Modal (Y) pada perusahaan Manufaktur LQ45.

\section{Penentuan Variabel Dominan}

Uji dominan digunakan untuk mengetahui variabel mana yang dominan diantara variabel bebas yang terdiri dari Ukuran Perusahaan, Profitabilitas dan Resiko Bisnis terhadap variabel terikat yaituResiko Bisnis, maka dilakukan dengan melihat rangking koefisien regresi yang di standartkan $(\beta)$ atau standartdized of coefficient beta dari masing-masing variabel bebas yang signifikan, variabel yang memiliki koefisien $(\beta)$ beta terbesar merupakan variabel bebas $(\mathrm{X})$ yang dominan pengaruhnya terhadap variabel terikat $(\mathrm{Y})$. Adapun data dari hasil pengujian variabel dominan disajikan dalam tabel 6 .

Berdasarkan Tabel 6, dapat diamati bahwa dari ketiga variabel bebas yang terdiri dari Ukuran Perusahaan, Profitabilitas dan Resiko Bisnisdapat diketahui bahwa ternyata variabel Resiko Bisnis (X3) mempunyai nilai koefisien $\beta$ (beta) terbesar yaitu sebesar 1,072. Sehingga dapat disimpulkan bahwa variabel bebas yang mempunyai pengaruh dominan terhadap variabel terikat Struktur Modal adalah Resiko Bisnis(X3). Sehingga hipotesis ketiga yang menyatakan Ukuran perusahaan mempunyai pengaruh dominan terhadap Struktur Modal $(\mathrm{Y})$ tidak terbukti kebenarannya.

Tabel 6

Hasil Perhitungan variabel Dominan Coefficients $^{\mathrm{a}}$

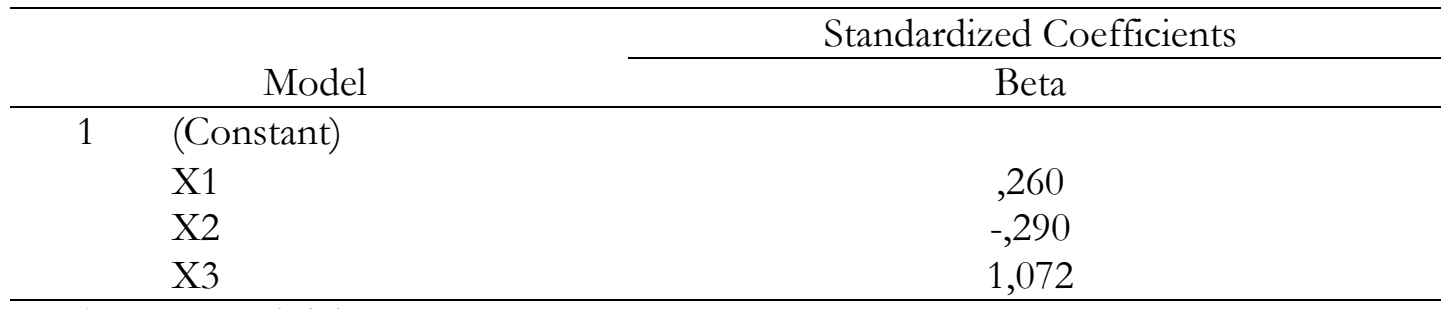

Sumber: Data Diolah, 2020 


\section{SIMPULAN DAN SARAN}

Bahwa Ukuran Perusahaan(X1), Profitabilitas(X2), dan Resiko Bisnis (X3) berpengaruh secara simultan dan Signifikan terhadap Struktur Modal (Y) pada perusahaan Manufaktur LQ45. Bahwa Profitabilitas secara parsial tidak berpengaruh sedangkan Ukuran perusahaan dan Resiko Bisnis secara parsial dan signifikan berpengaruh terhadap Struktur Modal pada perusahaan Manufaktur LQ45. Bahwa Variabel Resiko Bisnis yang berpengaruh secara dominan karena memiliki nilai yang terbesar dalam koefisien beta standardized sebesar 1,072 dibandingkan variabel bebas lainnya. Jadi jika perusahaan menginginkan Struktur Modal yang baik maka perusahaan sebaiknya memperbaiki 3 variabel yaitu Ukuran perusahaanm profitabilitas dan Resiko Bisnis tanpa meninggalkan salah satunya. Dari hasil penelitian secara parsial bahwa Profitabilitas berpengaruh negatif terhadap Struktur Modal dengan hasil thitung-4,626. Dengan hasil yang negatif perusahaan seharusnya bisa memperbaiki kinerja perusahaan hingga profit tetap setabil atau bahkan bisa meningkat, karena tidak jarang investor lebih tertarik dengan profit yang tinggi. Dari hasil penelitian diketahui bahwa variabel Ukuran Perusahaan dan Profitabilitas memiliki pengaruh kecil dalam uji Dominan terhadap Struktur Modal, maka perusahaan perlu memperhatikan Variabel Ukuran Perusahaan dan Profitabilitas dalam perusahaan untuk menjaga kestabilan perusahaan kedepannya. Bagi Perusahaan Manufaktur yang terdaftar di LQ45 didalam menjalankan sebuah perusahaan ada baiknya tetap memperhatikan aspek-aspek terkecil yang bisa mempegaruhi Struktur Modal perusahaan, agar nantinya perusahaan dapat berjalan lancar tanpa adanya hambatan kedepannya dan memperkecil terjadinya resiko kebangkutan.

\section{DAFTAR PUSTAKA}

Ardiana, Agus., dan Adiyana, Sabo, Nicko. 2014. "Pengaruh Ukuran Perusahaan, Risiko Bisnis, Pertumbuhan Aset, Profitabilitas Dan Likuiditas Pada Struktur Modal.” EJurnal Akuntansi Universitas Udayana.

Fahmi, and Irham. 2015. Pengantar Manajemen Keuangan Teori Dan Soal Jawab. Bandung: Alfabeta.

Kasmir. 2017. Analisis Laporan Kenangan. Jakarta: PT Raja Grafindo Persada.

Munawir, S. 2014. Analisis Laporan Keuangan. Yogyakarta: Liberty.

Prabansari, Yuke dan Hadri Kusuma. 2014. "Faktor-Faktor Yang Mempengaruhi Struktur Modal Pada Perusahaan Manufaktur Go Public Yang Terdapat Di Bursa Efek Jakarta Sinergi,.” Edisi Khusus On Finance 1-15. 